\title{
A Pragma-Stylistic Study of Al Burdah Ode by Al Busiri and its Rendering into English
}

دراسه أسلوبية تداولية لقصيدة البردة للبوصيري وترجماتا إلى الإنحليزية

الباحثة/شاهيناز حسين احمد الإنايه

باحثة دكتوراة بقسم اللغة الابحليزية



ان المنهج الذى سيتم تطبيقه بالرساله يسمى التحليل الاسلوبى التداولى ، سيتم القاء

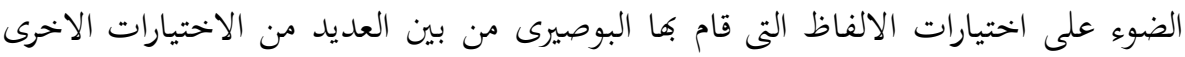

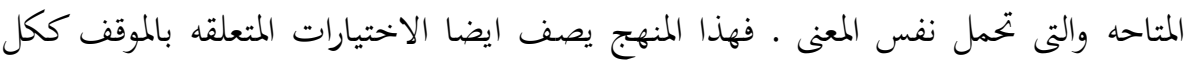
والذى تم استخدام اللغه فيه متضمنا ما يعرفه وما لا يعرفه المشتركون بالحوار ـ والمعنى الذى يريد



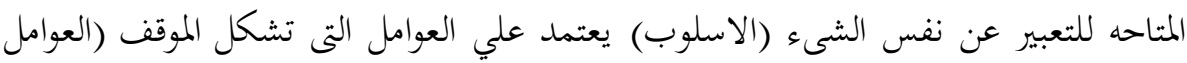
التداوليه) ، فهو يتضمن اعتبارمستخدمى اللغه و العلاقه التى تربط بينهم والموقف الذى يتواصلون

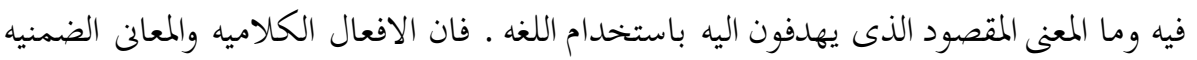
ومفاهيم السياق المتبادله تعتبر هامه لتفسير معنى النص المراد دراسته ـ لذا سيتم تحليل الاختيارات الاسلوبيه التى قام بها الشاعر ضمن سياق النص والتى تتضمن الكنايه- الاستعاره- التوكيد

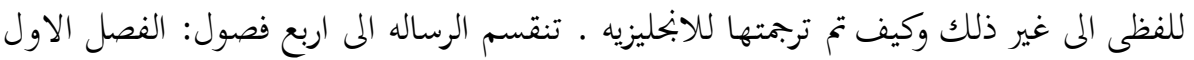

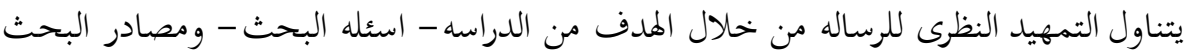
ثم فرضيات البحث ـ الفصل الثان يلقى الضوء على الاطار النظرى للدراسه والذى سيستخدم في الني التحليل الاسلوبى التداولى للقصيده ـ الفصل الثالث هو تحليل اسلوبى تداولى لقصيده البرده

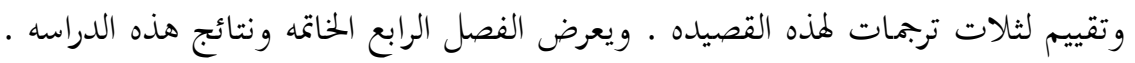

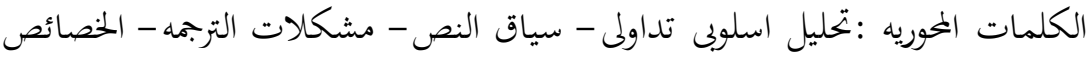

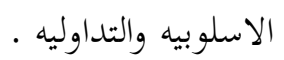

\section{Abstract}

The study is meant to be a Pragma-Stylistic study of $\mathrm{Al}$ Burdah Ode by Al Busiri. Stylistic features of the Ode are analyzed within a pragmatic framework, where the meaning 
of the text will be investigated in relation to the context of situation. The study is meant to show the importance of context in reaching a better understanding of the implied meaning of the writer. The study also attempts to investigate three English translations of the Ode, by Thoraya Mahdi Allam, Shahid Gill, and Muhammad Jamiu.

Key words: Pragma-Stylistics- context of situationimplied meaning- translation.

\section{Introduction}

Pragma-stylistics is stylistics but with a pragmatic component added to it. Pragma-stylistics pays special attention to those features which a speaker may choose from a range of acceptable forms in the same language that would semantically be equivalent, but might perform or achieve different objectives. Davies (2007, p106) states that pragmastylistics is concerned with the application of pragmatic theories to literary texts to present an explanation about the way literary language is used in context.

\section{Aim of the study}

This study aims at providing a pragma-stylistic analysis to $\mathrm{Al}$ Burdah's Ode, besides showing the importance of context in reaching a better understanding of texts, and investigating the effectiveness of implicature and how it can be used in the interpretation of literary texts.

\section{Research Questions}

The study attempts to answer the following questions:

1- How can a pragma-stylistic analysis help in reaching a better understanding of text?

2- Whether the translation retains the essence of the original poem or not? 
3- How is context important in understanding the writer's implied meaning?

\section{Sources of Data}

It was a data driven of text based study. One of the most popular odes of Al Busiri titled Al Burdah is selected, and three of its translations by Thoraya Allam, Shahid Gill, and Muhammad Jamiu are being selected.

\section{Method of Research}

The following procedures are followed:

- Definition of terms

- Analyzing and discussing data

\section{Theoretical Framework}

According to Missikova (2007, p92), the implementation of pragmatic dimensions in stylistic analysis means to focus on analyzing and understanding of the sociocultural, political or historical features of the text. Considering the aims of our stylistic analysis, the meaning studied within the text is the one created in a flow of communication, which is within a discourse between the author and the reader. The ode is classified into ten sections according to the pragmatic functions it expresses, and their correlative rhetorical devices. The following part will provide a selection of verses from the Ode followed by the English translations.

\section{On love and Complaining of its passion}

In this section the poet expresses his deep love to Prophet Muhammad

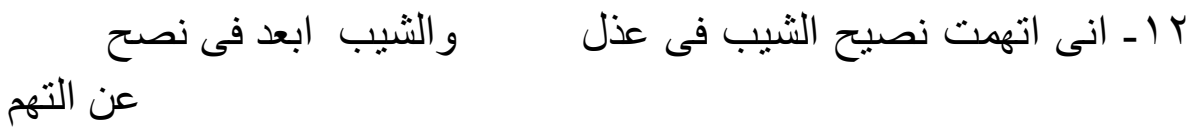


The poet likens his white hair to a person who gives him a sincere advice to stop committing sins. For the appearance of white hair is a sign of old age and the approach of death.

We can also notice the repetition of the word "الثنيب" /afJayb/ (white hair), a repetition which, according to Badawi (1978, p289), Hilal (1980, p240), and Yaqout (1995, p447), is a method of foregrounding, it is a fundamental device of intensification and emphasis. They also add that repetition is a kind of eloquence; it presents a simple emotion with force, besides producing a climatic effect. Moreover, according to Hilal (1980, p239), the repetition of a sound, syllable, word or phrase, is a basic unifying device, the exact repetition of sounds within a line serves as a variety of internal rhyme. Thus, we can sense an internal rhyme in the verse under study, moreover the repetition of / $/ \mathrm{a} \int \mathrm{Jay} /$ makes it stand out, to serve the pragmatic function of assertion. Repetition is considered a device that emphasizes an idea through reiteration. It is a major rhetorical strategy for producing emphasis, which is necessary to fix the attention of the reader on the key-word of the utterance.

The verse is translated as follows:

\section{Thoraya:}

I did suspect my greying hair's advice

As it blamed me

Though grey hair should for its advice,

Far from suspicion be.

\section{Muhammad Jamiu:}


Indeed, I am even suspicious of the elders' advice even though the advice (wisdom) of old age should be far beyond suspicion.

\section{Shahid:}

I regarded the advice of the elders with suspicion in reproaching me. (No doubt) the wisdom in the advice of the elders is above (any) suspicion.

By reviewing the translations, it is obvious that the two translators, Muhammad Jamiu and Shahid, misunderstood the connotation of the word /?a $\int \mathrm{ayb} /$, which the poet uses to imply that he is getting old, and the white hair that started to appear in his head are witnesses of his old age. Accordingly, they didn't preserve the personification intended by the poet.

\section{A warning against the Desires of the soul}

In this section the poet warns the reader from following the desires of the spirit

$$
\text { r r ـ و استفر غ الدمع من عين قد امتلأت من المحارم و الزم حميه }
$$

الندم

The verse begins with the imperative verb "استفرغ /?istafriy/ (shed tears), which serves the pragmatic function of guidance. In the same verse, the poet confirms his view by using the affirmative tool "قد" /qad/, which is an assertive that co-occurs with the past tense verb, and has the semantic communicative function of affirming the inevitability of the action denoted by the verb, which is an implicature of the fact that your eyes have definitely seen forbidden sights. Affirmation tool is a linguistic mechanism of making a notion more salient than other notions, it serves the perlocutionary effect of highlighting a given proposition and 
relaying the text producer's intended goal to the addressee. Moreover, we can observe the antithesis between - استفرغ ") "امتلأت, /istafriy/ and /?imtal?at/ (full of ), which strengthens the meaning.

We also have another imperative verb "الزم" /?ilzam/ (adhere), which serves the perlocutionary effect of guidance. The poet advises man to shed tears, as a sign of repentance from the same eyes that have seen forbidden sights.

The verse is translated as follows:

\section{Thoraya:}

From eyes that had their fill

Of sights forbidden, let each tear

Flow freely, and to penance's protection

Thus adhere

\section{Muhammad Jamiu:}

And shed tears from eyes full of forbidden sights, and continue to feel remorse

\section{Shahid:}

And shed tears from (those) eyes which have became full of forbidden sights and mark an obligatory (duty upon yourself) to guard your eyes from forbidden things.

By reviewing the translations, we notice that Thoraya foregrounded "Eyes", by beginning the speech act with it, where she missed the poet's intended meaning, for the poet begins his speech act with an imperative that attracts the attention of the reader. This imperative serves the pragmatic function of highlighting and giving 
prominence in order to psychologically prepare the reader for the coming advice, where he likens the eye to a container full of tears, and orders man to empty it. I believe that Thoraya managed to render the imperative verb "الزم", by using her lexical choice "adhere" which means "to stick firmly to something" thus, serving the same perlocutionary effect of the source text . However, the three translators managed to render properly the poet's intended meaning.

\section{Praising the Holy Prophet}

$$
\text { 9 بـ ظلمت سُنه من احى الظلام الى ان انتكت قدماه الضر }
$$

من ورم

In this verse we have an instance of metaphor, where the poet likens those who abandon sleeping at night to worship Allah, as if they endow the dead night with life. Besides, there is also an instance of hypallage in the lexical choice "الظلام/2/azalaam/ (darkness), where this lexical choice denotes night.

However, we can also observe that the word "ورم" /waram/ (swelling) is indefinite, to serve the perlocutionary effect of glorification, showing the intense pain of Prophet Muhammad. We can also notice the polyptoton between the verb "الظلام" /zalamt/ (wronged), and the noun" /?azzalaam/ (darkness). As mentioned before, polyptoton is one of the methods of foregrounding.

The verse is translated as follows:

\section{Thoraya:}

I've never performed added devotions

Of the Prophet, who in pain

A night- long vigil kept until

His swollen feet*complained 
*the Holy Prophet's feet became swollen as a result of the long hours he spent in his devotions

\section{Muhammad Jamiu:}

I have wronged the way of him who kept awake in the dark night, praying until his feet complained of their swelling.

\section{Shahid:}

I disobeyed the Sunnah (the way of passing life) of (Nabi Akram) who passed the nights in worship until his feet complained of injury due to being swollen.

By reviewing the translations, it is apparent that the poet's choice of the word "ظلمت" (do injustice- do wrong to) is beautiful which implies his great sin for not observing sunnat Prophet Muhammad. Thoraya and Shahid did not manage to render this lexical choice properly for " I have never performed" and "disobeyed" do not convey the same layers of meaning embedded in the poet's lexical choice, hence not creating a similar perlocutionary effect on the target language reader.

Moreover, the beautiful metaphor of endowing life to the dead night is not maintained by any of the three translators, who could have rendered it as "who livened the dark". Thus missing the poet's image and, accordingly, not creating a similar perlocutionary effect on the target language reader, by showing the importance and the beauty of worshipping Allah at night, and which is an implicature of the poet's dark and dead nights for not observing the Prophet's Sunnah.

\section{Blessings of the Birth of the Holy Prophet}


عليه و النهر ساهى العين r T - و النارخدامد الأنفاس من أسف

من سدم

The poet in this verse continues relating the events that took place on Prophet Muhammad's birth. He likens the fading of the fire of Persia, which implies the remorse of the fire for being worshipped by infidels, to a person who has gone out of breath, which is considered one of the creative metaphors by the poet. The poet also uses another beautiful metaphor in the second speech act, where he likens the river Sawa that flooded and lost its spring (current/ course), which implies the river's grief for being away from Prophet Muhammad, to a person who is crying out of sorrow.

The verse is translated as follows:

\section{Thoraya:}

The sacred fire* abated was

From sorrow and from woe.

Likewise, the river as it grieved,

Its course forgot to flow*

*this fire has been alight for a thousand years in Persia, but on the birth of the Holy Prophet, its flame flickered and subsided.

*the river Euphrates.

\section{Muhammad Jamiu:}

And their sacred fire faded and died from remorse, while their river forgot its source and dried up from sorrow.

\section{Shahid:}

And the fire (of the Persians) was extinguished out of regret; and the rivers (of Persia) dried up with wonder (and excessive sorrow). 
By reviewing the three translations, it is obvious that the first metaphor was only maintained in the rendering of Muhammad Jamiu. Accordingly, the other two translators failed to create a similar perlocutionary effect on the target language reader.

\section{Miraculous Deeds of the Holy Prophet}



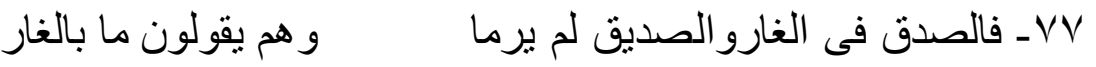

According to Al Zarkashi (2017, p239) and Al Hanafi (n.d., p194), the poet in this verse describes the Prophet by using the "الهصد" (الصدق" /as sidq/ which literally means the truth. Here the poet uses the verbal noun to imply that all the truth is embedded within the Prophet. The poet also uses "الصديق /?assiddiiq/ (the most sincere) which is a hyperbole of the pattern "فعيل to denote his companion Abu Bakr. In this figure of speech, deliberate exaggeration is used for emphasis; it may be used to evoke strong feelings or to create a strong impression. The pragmatic function of hyperbole, according to Abdul Raof (2006, p252), is to describe the state of someone or something in an exaggerated manner that exceeds the customary limit. Leech (1969, p167) quotes Fowler's definition of hyperbole as " the use of exaggerated terms for the sake not of deception, but of emphasis".

In the first speech act, we have a beautiful instance of polyptoton, which can be classified as one of the obvious methods of foregrounding. On the linguistic level, this repetition is employed as a cohesive vehicle to achieve a communicative purpose, while on the rhetorical level, it achieves polyptoton which is employed for a stylistic effect. 
" The polyptoton here is between the two nouns " /?assidq/ (the truth) and "الصديق" /?assiddiiq/ (the trusting one). Besides there is another instance of polyptoton between the verb "يرما" /yarima/ (leave), and the noun "ارم" /?arim/ (someone).

The verse is translated as follows:

\section{Thoraya:}

The true one* and the trusting one*

This cave they did not leave

Whilst unbelievers stated that

No one was in the cave.

*the true one: the Holy Prophet

*the trusting one: Abu Bakr.

\section{Muhammad Jamiu:}

The disbelievers could not see the Truth and the Truthful one, and they were saying there is no one in the cave.

\section{Shahid:}

And the Truth (the Prophet) and the True (Abu Bakr) were not seen in the cave (by the disbelievers) and they were saying, "There is no one in the cave".

By reviewing the translations under study, it is apparent that the verbal noun "الصدق", is maintained in the translations of Muhammad Jamiu and Shahid only. Accordingly, it conveys a similar perlocutionary effect on the target language reader, implying that all the truth is embedded in the Prophet. Furthermore, the verbal sentence , is rendered in the progressive form by Muhammad Jamiu and Shahid, serving the pragmatic 
function which reflects the duration of the infidel's search, for it takes them some time looking for the Prophet and his Companion.

\section{Findings and Conclusion}

The study shows that in a pragma-stylistics analysis of poetry, context plays a very important role, and it shows how the knowledge of all the contextual features is important to understand the message of the poem. It is not what is said but how it is said that matters.

As previously mentioned, the researcher takes into consideration how the readers interpret the translation, their response to the target text, and whether the translated version has a similar perlocutionary effect on the target language reader. To achieve this, the researcher compares the reader's response to the target text, with that of the source text reader's to the source text.

The researcher is also concerned with achieving pragmatic equivalence, which mainly deals with implicatures, which is used to refer to what is implied and not to literal meaning. So, the researcher may discover whether translators worked out the meaning of implicatures in the source text.

The thesis also shows the difficulties that may face translators, for the task of translators is to eliminate misunderstandings, which can also be referred to as culture bumps, which are features that hinder cross- cultural interaction. Xie (2011, p205) states that a poem is an event that brings about a singular but dynamic conjucture of text and context, and what matters is the invisible (pragmatic) 
context. This context may include factors such as the poet's beliefs, as well as implicitly shared values of the poet's culture or time. So, the total unity of the poem's words and what they connote are more than its semantic meaning.

The pragma- stylistic analysis of the Qasidah reveals the following:

1- Some languages have concepts that are unknown to the people of other languages, words that refer to concepts so specific to that language, which can not be translated, but have to be described to the target language reader. This is one of the tasks of the translator, to bridge the gap between the two cultures. So, the translator must know not only the two languages (source and target), but also the two cultures. Otherwise, this might lead to a misinterpretation on the part of the translator, and, accordingly, on the target language reader who has no access to the source text except via the translation.

2- The importance of context and understanding the emotive meanings of words for translation is clearly shown in the mistranslations in verse 157 "منعكس", which was mistranslated by some translators as "reverse", and in verse 104 " which was mistranslated by some translators as well, and in verse 115 مليث- اوليث", which were treated by some translators as synonymous, and accordingly, the translation did not serve properly the poet's intended meaning.

With respect to a pragma- stylistic analysis of the Qasidah, the following suggestions can be drawn:

1- Footnotes or commentaries can be used as translation enforcements which have a significant added 
value to the communicative process of translation. Footnotes or commentaries are useful for the comprehension of culture- specific words or images. However, in order to verify our claim that footnotes constitute a translational requirement for clarifying certain concepts and images, the researcher provided a number of verses whose translation requires and is dependent on footnotes, within the text- notes or commentaries. There are many cases where the translation is without footnotes or commentaries, which can lead to serious misconceptions and misunderstandings.

2- The different figures of speech embedded in the verses should be clarified to the target language reader, since these figures are essential for the communication of the spirit of the poet's message. Thus, the translator should look for a way to express the rhetorical beauty of such figures.

3- The classification and identification of speech acts play an essential role in communication, so it is important to be able to distinguish between the form of a particular expression and its function, in order to create properly a similar perlocutionary effect on the target language reader.

5- It is so important for the translator to understand that the emotional attitude, which is crystallized in a poem, may be derived from real events in the poet's life.

6- Stylistic analysis shows the translator the ideas of the author and the meaning behind them. Besides, the translator must know not only the source and target languages, but also their cultures.

\section{References}


1- Abdul- Raof, H. (2006). Arabic Rhetoric: A Pragmatic Analysis.

London: Routledge.

2- Al- Hanfi, A.O., (n.d.). Qasidah Al- Burdah. Pakistan:

Al- Madinah.

3- Allam, T.M. (1987). Al Busiri's Burda: The Prophet's Mantle.

4- Al- Zarkashi, M.B. (2017). Sharh Al-Burdah. Cairo: Ilm.

Cairo: General Egyptian Book Organization Press.

5- Badawi, A. A. (1978). Min Balaghit Al- Qur'an. Cairo: Dar Nahdit Masr.

6- Davies, W.A. (2007). An introduction to Applied Linguistics. Edinburgh: Edinburgh University Press

7- Gill, S. H., (2006). Qaseedah Burdah Shareef. Lahore: Minhaj -ul-

Qur'an International Publication.

8- Hilal, M.M. (1980). Jaras Al- Alfaz wa Dilalatiha fil Bahth Al Balaghi wal Naqdi ind Al Arab. Bagdad: Dar Al Rasheed.

9- Jamiu. M.,( 2011). Praising The Prophet with Imam al-Busiri's

Qasidah al Burdah. In. Owaisi, F. (Ed). Capetown: Baye Media.

10- Leech, G.N.(1969). A Linguistic Guide to English Poetry. London: Longman. 
11- Missikova, G. (2007). Pragmatic Dimensions in Stylistic Analysis. Brno Studies in English, 33, 91-100.

12- Yaqout, M.S. (1995). Ilm Al- Jamal Al- Lughawi. Egypt: Dar Al- Ma'rifah Al- Jami-yah. 